\title{
Toward a Socialism for the Future, in the Wake of the Demise of the Socialism of the Past
}

\author{
Thomas E. Weisskopf
}

\begin{abstract}
In this paper I seek to explore what kind of socialist system can best make good on the socialist commitment to equity, democracy and solidarity - in the wake of the failure of the political-economic systems of the USSR and Eastern Europe. I identify and explore two alternative models of socialism - market socialism and participatory socialism - and conclude by endorsing a form of democratic, self-managed market socialism.
\end{abstract}

\section{INTRODUCTION}

What is socialism really all about? The revolutionary events of 1989 in Eastern Europe, and the enormous changes that have taken place in the former Soviet Union since then, have raised this question with renewed acuity.

The idea of socialism developed historically out of opposition to the reality of capitalism. The basic goals of the movement for socialism have thus been formulated in reaction to the perceived ills of capitalism. To condense an enormous literature on the subject of socialist goals, I would suggest that socialism has been committed most fundamentally to the following objectives:

(1) Equity: as against the capitalist reality of great inequalities of income and wealth, socialism calls for an egalitarian distribution of economic outcomes and opportunities by class, race, gender, region, etc.

(2) Democracy: as against liberal democracy in the political sphere, which has characterized the most democratic of capitalist societies, socialism calls for economic democracy that enables people to exercise control over their own economic fate.

(3) Solidarity: as against the celebration of the individual under capitalism, socialism calls for the promotion of solidarity among members of communities extending from the neighborhood to the whole of society - encouraging people to develop the sense and the reality of themselves as social rather than simply individual beings.

Department of Economics, University of Michigan.

This paper grew out of my involvement in lively and wide-ranging discussions of Marxism and socialism over the Progressive Economists' Network. I am grateful to countless PEN participants. I would like to mention in particular my indebtedness to Michael Lebowitz for his role in a series of stimulating debates. I would also like to thank Sam Bowles, Michael Goldfield, Fred Moseley, David Kotz and Victor Lippit. 
In addition to its commitment to these goals that distinguish it from capitalism, socialism has historically been committed to the improvement of people's material standards of living. Indeed, in earlier days many socialists saw the promotion of improving material living standards as the primary basis for socialism's claim to superiority over capitalism, for socialism was to overcome the irrationality and inefficiency seen as endemic to a capitalist system of economic organization. In the present time - at least in the more affluent parts of the world, where capitalism has brought substantial improvements in living standards and where problems of ecological balance loom more important than problems of starvation or malnutrition - this growth objective has receded in importance for socialists. However, the extent to which any resource-using economic or social objective can be achieved - whether it be improving the environment or eliminating hunger - remains dependent on the degree of efficiency with which the system of economic organization operates. I will therefore articulate - as do most socialists, explicitly or implicitly — one additional important socialist objective:

(4) Efficiency: socialism requires that resources be used wisely and non-wastefully in order that resource-using economic and social goals can be more successfully achieved.

In this paper I seek to explore what kind of socialist system can promise to make good on the socialist commitment to these goals, in light of the manifest failure of the political-economic systems of the U.S.S.R. and Eastern Europe to do so. I will begin in section I by discussing the implications of the events of 1989; this leads me to identify two potentially fruitful models for socialism in the future - market socialism and participatory socialism. Sections II and III explore in turn each of these two forms of socialism; I pose and seek to answer questions with which critics have challenged the advocates of each. I conclude in section IV by articulating the kind of socialism that seems to me to hold the greatest promise of living up to time-honored socialist ideals.

\section{THE IMPLICATIONS OF 1989}

There can be no doubt that 1989 marks a watershed in the history of socialism. Although, as we now know, the disintegration of the political-economic systems of the U.S.S.R. and Eastern Europe had already been underway for at least a decade, 1989 was the year in which the failure of these systems became visible to one and all. As people took to the streets in Eastern Europe, rulers scrambled to dissociate themselves from the old order. After the failed coup against Mikhail Gorbachev in August 1991, it has become perfectly clear that even in the successor states of the Soviet 
Union itself there can be no return to the political-economic system of Lenin, Stalin or Brezhnev.

The events of 1989 are clearly the main reason why we (and many others) are now discussing the future of socialism. Of course, the conventional wisdom is that socialism has no future - only a past. As Robert Heilbroner (1989: 4) put it: "Less than 75 years after the contest between capitalism and socialism officially began, it is over: capitalism has won." We on the Western Left reject that conventional wisdom because we argue that where there has been economic failure - in Eastern Europe, in the Soviet Union, if not in all of the Communist Party-directed socialist economies - it has not been a failure of true socialism, but of something very different.

Is there anything, then, for us to learn from 1989? Indeed, I believe there are several important lessons.

First of all, we must recognize that Communist-Party-directed socialism - the type characteristic of all actually existing socialist systems the world has known' - was a worse economic failure than most of us had previously been willing to admit. In the Soviet Union and Eastern Europe, at least, it not only failed to provide much growth and efficiency in its last decade or two, it also failed to achieve real equity, and it was ecologically disastrous. ${ }^{2}$ In these respects the accomplishments of CP-directed socialism have been somewhat more impressive in less-developed economies such as those of China and Cuba, especially as compared with their own past experience; but even in these more favorable instances, there have been many disappointments. And, of course, all these societies have been extremely undemocratic, and almost always deeply alienating to their workers and citizens.

Second, we cannot simply dismiss this dismal record as having nothing to do with socialism. Of course CP-directed socialism is a far cry from the democratic, egalitarian and solidaristic society that most of us on the Left have advocated. There are even some Western Leftists who have consistently refused to apply the label "socialist" to the societies at issue. Nonetheless, most Western Leftists are to some extent tainted by the record of the CP-directed state socialist countries.

For one thing, these countries have exhibited certain characteristics that have been associated with socialism, not just by CP officials and old-fashioned socialists, but by many contemporary Western Leftists - e.g., society-wide control of capital formation, strict limitation of the role of private ownership, strong curbs on the operation of markets, guarantees of employment and basic social services to all citizens. Moreover, many on the Left have compared aspects of the performance of the CP-directed socialist economies - e.g., their long-term growth record, their egalitarianism, their social services - favorably with that of capitalist economies. Even when such a favorable comparison is justified by the evidence (e.g., in comparing many of Cuba's social achievements with those of other Latin American 
countries), to claim that it represents any kind of victory for socialism is to accept that what has been constructed in countries like Cuba is indeed a form of socialism.

Confronted with such concerns, many of us have held out hope that at least some of the CP-directed socialist systems - however distorted and unsatisfactory their current structure - might evolve toward a truer form of socialism. ${ }^{3}$ This again lends credence to the notion that the CP-directed socialist systems do have something to do with the socialism that we advocate.

Perhaps, then, 1989 represents the vindication of a small minority of Western Leftists - those who have always sharply criticized the CP-directed socialist systems and who have consistently refused to consider them as having anything whatsoever to do with socialism. There are two main schools of socialist thought on the Western Left that have been "pure" in this respect; I believe that they can usefully be characterized as liberal-democratic and communitarian, respectively. ${ }^{4}$

Liberal-democratic socialists have stressed the general socialist goal of democracy, arguing in particular that liberal democracy - a political system including constitutionally protected civil rights and liberties, democratic elections, etc. - is an absolute prerequisite for a socialist society worthy of the name. This implies that socialist economic institutions, designed to promote such other socialist goals as equity and solidarity, must be built upon a liberal-democratic political foundation. The construction of socialist society is seen not as the replacement of "bourgeois democratic institutions" by some entirely different and superior form of democracy, but as deepening the democratic nature of these institutions and extending them from the political through the social to the economic arena. From this perspective, the authoritarian character of political rule in all of the CP-directed socialist societies has disqualified them from the very start as exemplars of socialism. ${ }^{5}$

Communitarian socialists are also committed to democracy, but democracy of a less liberal and more participatory kind. In the communitarian vision it is the socialist goal of solidarity which receives the greatest emphasis people are to develop and sustain solidarity as active participating members of communities ranging from the neighborhood and the workplace to the society as a whole. The political and economic institutions of liberal democratic capitalism are to be discarded; what is envisaged is a revolutionary transformation to an egalitarian participatory society in which people jointly and directly control their own fate. From this perspective, the CP-directed socialist societies are rejected because of their retention of many of the individualistic patterns and hierarchical structures of capitalist societies, as well as for their betrayal of democratic ideals. ${ }^{6}$

Liberal-democratic socialists generally advocate a form of democratic market socialism, in which liberal democracy is combined with an economic 
system characterized by predominantly collective forms of ownership of the means of production and by the use of markets as the predominant means of resource allocation and distribution - subject to some government planning, intervention and regulation. Collective ownership is designed to promote egalitarianism in both economic and political spheres; markets are seen as indispensable both to individual freedom of choice and to efficient resource location; and government regulation is seen as necessary to assure that the general interest prevails over particular interests and to limit the development of substantial inequities.

Communitarian socialists generally advocate a form of democratic participatory socialism, in which there is collective social control of the means of production and in which decentralized participatory planning institutions replace the market as a mechanism for resource allocation and distribution. This is a vision of socialism in which, to put it in Marxist terms, both exploitation and alienation are overcome; thus not only private property but also markets must be abolished. Instead of responding as independent self-interested individuals to market signals in the economic arena, people are to develop and sustain themselves as interdependent social beings as they participate together in making consumption and production decisions.

Both the market socialist model envisaged by the liberal-democratic socialists and the participatory socialist model envisaged by the communitarian socialists are sharply differentiated from the CP-directed socialism of the past. In the following two sections of this paper, I will consider market socialism and participatory socialism in more detail.

\section{MARKET SOCIALISM}

The idea of a market-based form of socialism was first given serious attention in the 1920s, when it was promoted by people within the social-democratic wing of Marxism as a desirable alternative to the marketless form of socialism identified with Marx's vision of full communism and embraced by the Bolshevik wing of Marxism. The first systematic theoretical exposition of the functioning of a market socialist economy was undertaken by Oskar Lange in the 1930s, who has ever since been recognized as the pioneer of market socialism. ${ }^{7}$ Lange's original model involved both actual markets (in consumer goods and labor), simulated markets (in producer goods) and a limited but critical role for central planning (e.g., in determining the rate of investment and the distribution of income). All enterprises were to be owned by the government, but run according to profit-maximizing rules by independent managers. Since Lange's exposition of his original model of market socialism, a great deal of work has been done by advocates of market socialism - many of them economists from and/or interested in the post-World War II Eastern 
European countries - seeking to improve upon Lange's model while dealing with various problems raised by critics. ${ }^{8}$

Out of this continuing literature on the conceptualization of market socialism have emerged a variety of different models, but they all share the same central defining purpose. Market socialism seeks to promote socialist goals of equity, democracy and solidarity while largely retaining one major feature of capitalist economies - the market - but largely replacing another major feature of capitalism - private ownership of the means of production. For at least the major sectors and/or the most important enterprises in the economy, market socialists propose some form of social ownership of enterprises.

"Ownership" is a complex concept encompassing a variety of rights, which can potentially be assigned to a variety of different people. For our purposes it will be useful to identify and distinguish two such rights in particular: (1) the right to enterprise control and the right to enterprise income. The right to control confers the prerogatives and responsibilities of management: those who control the enterprise (or their representatives) make the decisions about how the enterprise will be operated, who will work in it and under what conditions, whether or not any aspects of the enterprise are to be expanded, contracted, sold or liquidated, etc. The right to income confers a claim to the surplus generated by the enterprise - i.e., the net (or residual) income after fixed obligations have been paid. ${ }^{9}$

The standard capitalist enterprise is owned by private individuals or shareholders who have (ultimate) control over management according to the nature and the amount of their ownership shares; a small number of individuals or shareholders may have predominant control. Under market socialism enterprise control is social rather than private. Control of a market socialist enterprise is held by a community of people, each of whom - in principle - has an equal say in the management of the enterprise; as a practical matter, this (ultimate) control is usually exercised via appointment of managerial staff. There are two principal variants of such social control, depending on the nature of the community in whom control rights are vested:

(1) Public management: enterprises are run by managers who are appointed by and accountable to an agency of government (at the national, regional or local level), which agency represents a corresponding politically constituted community of citizens. ${ }^{10}$

(2) Worker self-management: enterprises are run by managers who are appointed by and accountable to those who work in them (or their elected representatives), with control rights resting ultimately with the community of enterprise workers (on a one-person one-vote basis). ${ }^{11}$

In the standard capitalist enterprise, ownership by private individuals or shareholders conveys not only control rights but also income rights - again according to the nature and the amount of their ownership shares. Under 
market socialism income rights are held socially rather than privately. The surplus of the market socialist enterprise accrues to a community of people in a relatively egalitarian manner. Here again there are two principal variants of such social claims to income, depending on the nature of the community holding the claim:

(1) Public surplus appropriation: the surplus of the enterprise is distributed to an agency of government (at the national, regional or local level), representing a corresponding community of citizens. ${ }^{12}$

(2) Worker surplus appropriation: the surplus of the enterprise is distributed to enterprise workers. ${ }^{13}$

These two different ways of assigning control rights and income rights under market socialism can generate a matrix of four different possible market socialist models, since there is no $a$ priori reason why each set of rights must be assigned in the same way. As it happens, however, most contemporary advocates of market socialism lean primarily in one direction or the other: there is one school favoring what I will label the "public enterprise model," characterized by public management and public surplus appropriation, and a second school favoring the "worker enterprise model," characterized by worker self-management and worker surplus appropriation. ${ }^{14}$

Although the replacement of private with social control and income rights at the enterprise level is what most clearly distinguishes market socialism from (market) capitalism, advocates of market socialism also generally call for a greater degree of government intervention into markets than is the norm in capitalist economies. Such intervention does not primarily take the form of quantitative controls, of the kind associated with the discredited system of centrally planned socialism. Instead, it involves more extensive government provision of public goods and services, more extensive public capital formation, more extensive government regulation of enterprises and more extensive use of taxes and subsidies to internalize external effects that would otherwise be neglected by individual consumers and producers in the market environment. The objective here is to shape the environment in which the market operates, and to use the market rather than replace it, so that market price and cost valuations will approximate true social benefits and costs. ${ }^{15}$ The difference between market socialism and capitalism in this respect is essentially one of degree rather than kind; apart from public control and income rights in enterprises, the economic role of government in a market socialist system differs little from that of government in the more regulated (e.g., social-democratic) capitalist systems.

Market socialism has been challenged both by those who question the ability of markets to function efficiently in the absence of capitalist private property rights, and by those who question the ability of social ownership forms to meet socialist goals in the context of markets. I have discussed 
elsewhere (Weisskopf 1992) the former line of criticism; here I will focus on the concern that market socialism is not really socialist enough. This latter concern tends to revolve around the following kinds of questions.

1. Don't market systems systematically undermine efforts to serve general public interests?

Markets provide an environment in which people are encouraged to find ways to better themselves at the expense of others - through individual rent-seeking behavior, the formation of self-aggrandizing coalitions, etc. As a result, there would appear to be a systematic tendency for the general social interest to be undermined by the pursuit of particular private interests.

This line of argument is theoretically plausible; yet it is not decisive. Rent-seeking behavior and self-aggrandizing coalitions of one kind or another can and will occur under any conceivable system of economic organization that permits some people to live better than others. Virtually every system will therefore require institutions that limit antisocial behavior. The only way in which an economic system of organization per se could eradicate the problem would be if that system, by virtue of its controls on individual patterns of living, precluded any individual from enjoying the gains from self-interested behavior.

Thus a solution to the problem of such behavior could come only at the price of strict limits on privacy and freedom of choice - a price that market socialists are unwilling to pay.

\section{Don't market systems unfairly reward good luck?}

In market capitalist economies people are rewarded for productive contributions due to the property they own (in the form of capital income); such rewards to property ownership not only have very unequal distributional consequences, but they are generally not necessary to assure deployment of the property in production. In market socialist economies people are rewarded primarily for productive contributions due to their own labor. ${ }^{16}$ Yet market socialism, like capitalism, maintains rewards to people's natural abilities (in the form of labor income), even though such rewards may not really be necessary to elicit the deployment of those abilities in production. Moreover, worker self-managed forms of market socialism are likely to favor those people who happen to work in prosperous areas or enterprises but do not necessarily work any harder or longer than other people who work in less prosperous areas or enterprises.

A more just system of economic remuneration would arguably link payment solely to differential personal effort and personal sacrifice, not to the luck of the genetic or economic draw. While market socialist systems do not achieve this ideal, they do not depart from it anywhere near as much as do capitalist systems. Moreover, to the extent that unwarranted returns to a person due to their luck in the genetic lottery or in economic circumstances 
remain, the resulting differentials can be diminished by a progressive system of income taxation. ${ }^{17}$

3. Won't any kind of market system lead to inequalities that contradict the socialist goals of equity and democracy?

Critics of the "market" within market socialism suggest that it will generate an elite minority of "coordinators" 18 - e.g., public investment bankers, public enterprise directors, self-managed firm managers, even government planners - who end up gaining disproportionate economic and political power, much as do capitalists within a capitalist system.

It is certainly true that under market socialism there must be some people occupying positions of key decision-making responsibility, and in all likelihood such people will have higher incomes as well as greater power than most of the rest of the population. Thus inequalities of income and power would surely develop under market socialism. But they would just as surely be much smaller than under capitalism - because market socialism eliminates most returns to property ownership, which is the predominant source of inequalities under capitalism. While there would still be ample scope for inequalities associated with differential skills, talents and responsibilities, it is hard to see how the equivalent of a propertied capitalist class could emerge from the more privileged strata of a market socialist society.

Although a market system could not assure anything close to full equality of income and power for all participants, neither could any economic system in a complex society. Such societies require sophisticated decision-making institutions of one kind or another; and there are bound to be great differences among people in their ability (or desire) to participate effectively in decision-making processes.

\section{Won't markets undermine solidarity and community?}

Critics of market socialism also argue that markets of any kind tend to breed selfish motives and competitive behavior on the part of producers and consumers, dividing people instead of uniting them, encouraging indifference to rather than empathy for others and discouraging the development of public-spirited community consciousness and solidarity.

To transact effectively in markets, people do have to think mainly in terms of their own individual (or family) welfare, while setting aside consideration for others; markets encourage anonymity, autonomy and mobility rather than community, empathy and solidarity. ${ }^{19}$ Market socialism thus admittedly does not provide direct support for a culture of community, empathy and solidarity. Yet it surely does provide a less hostile environment for the development of such characteristics than (market) capitalism because it attenuates, via greater egalitarianism and stronger democracy, the consequences of unfettered markets and unrestricted private property 
ownership. Although economic institutions are powerful social and cultural forces, they are neither monolithic nor omnipotent; hence community, empathy and solidarity may be fostered in other spheres of life even in a market system.

\section{Will market socialism be any more successful than social-democratic} variants of capitalism in achieving socialist goals?

Advocates of social democracy share the socialist objectives of advocates of market socialism, but they differ as to the best means to achieve them. Where market socialism seeks to promote the public interest, greater equity, democracy and solidarity primarily by transferring capitalist ownership rights to communities of citizens and/or workers, social democracy seeks to do so by government policy measures designed to constrain the behavior of capitalist owners and to empower other market participants. Thus social democrats do not try to do away with either the market or private property ownership; instead, they attempt to create conditions in which the operation of a capitalist market economy will lead to more egalitarian outcomes and encourage more democratic and more solidaristic practices than would a more conventional capitalist system.

Market socialists have traditionally been highly suspicious of social democracy, on the ground that its failure to attack head-on the source of capitalist power - private ownership of the means of production - would ultimately prevent it from attaining socialist objectives. But as models of market socialism have been refined over the years, the distinction between market socialism and social democracy has been somewhat blurred. Partly because of the problematic experience of East European CP-directed socialist economies with limited market-oriented economic reforms, advocates of market socialism have come to support an increasingly wide scope for markets and increasing autonomy for public and/or worker enterprises operating within the market environment. ${ }^{20}$ While such proposals do not amount to the restoration of full capitalist private property rights, they do open up opportunities for individuals to receive some forms of capital income.

The elimination of large-scale private property ownership under market socialism certainly leads to a much more equal distribution of income than obtains under conventional capitalism. Both theory and the actual experience of social democracy, however, suggest that government taxation and spending programs can substantially reduce the extent of income and wealth inequalities within a capitalist economy. As far as the pattern of enterprise management is concerned, there is also good reason to question how far market socialism really differs from social democracy. Market socialist enterprise managers, whether accountable to government agencies or to enterprise workers, are expected to operate their enterprises in such a way as to maintain profitability in a market environment; this means that they will 
typically have only limited leeway to steer the enterprises in a direction much different than would managers accountable to private shareholders. ${ }^{21}$ And, indeed, to prevent autonomous public enterprises or worker self-managed firms from acting in their own particular interest, as against the general social interest, it would in all likelihood be necessary for government to regulate them or their markets just as is done by social-democratic governments in a capitalist economy.

At a more fundamental level, market socialism does not dispense with individual gain incentives and the necessarily associated inequalities. Instead, it seeks:

(a) to link differences in rewards more closely to corresponding differentials in the actual productive effort contributed by people to the economy; and

(b) to reduce the extent of differences in rewards associated with differentials in productive effort, so as to reduce (greatly) the resultant distributional inequity without reducing (much) the incentives they generate. 22

Again, this is precisely what social democracy tries to do - albeit in a different way than market socialism. Social democracy achieves greater egalitarianism via ex-post government taxes and subsidies, where market socialism does so via ex-ante changes in patterns of enterprise ownership. As for serving the general social interest, market socialists and social democrats agree that, where the unfettered market will not achieve important social goals, the first option is to try to guide the market toward socially optimal behavior (via appropriate taxes, subsidies, etc., to internalize externalities by "planning with the market"); where this is not adequate, the second option is to replace price-and-market mechanisms by quantitative controls and/or direct state operation of enterprises.

On further reflection, one might well ask of market socialists: what compelling reason is there to restrict forms of enterprise ownership to types in which control and income rights accrue to (citizen or worker) communities rather than to private shareholders? Why not simply provide a level market playing field in which all types of enterprises can compete on a truly equal basis? Most contemporary market socialist models in any case allow for individual or small-scale private enterprise. Could not the problems of excessive wealth and power associated with large-scale private enterprise be addressed as easily and successfully via taxation and regulation as via restrictions on private ownership?

To sustain the superiority of the market-socialist over the social-democratic approach to achieving socialist objectives, I would argue as follows. In redefining and reassigning (to workers and/or communities) rights that form the point of departure for markets, market socialism intervenes into the market system before markets operate - while social democracy intervenes 
(mainly) after markets operate. This makes social democracy much more vulnerable to weakening or disintegration under political challenge, since tax-and-subsidy schemes and government regulation are much easier to reverse than changes in property rights. ${ }^{23}$ Moreover, the maintenance of property-owning capitalists under social democracy assures the presence of a disproportionately powerful class with a continuing interest in challenging social democratic government policies. Under market socialism there may well emerge a kind of managerial class with disproportionate power; but its power is likely to be less disproportionate because enterprise control rights and personal wealth will not be so highly concentrated.

\section{PARTICIPATORY SOCIALISM}

Although market socialism has become relatively popular on the Left in recent years, there is a much older socialist tradition that has always rejected the idea of including markets in anything other than a transitional phase following capitalism. Karl Marx wanted to rid the world not only of the inequalities associated with private property, but of the alienation and commodity fetishism associated with the operation of market systems. This was the Marxist tradition embraced by the Russian Bolshevik revolutionaries, and it remained an important part of the ideology - though not the practice - of Soviet socialism for decades after the Revolution of 1917. In point of fact, none of the "actually existing" CP-directed socialist economies of the U.S.S.R., Eastern Europe, China, Cuba, etc., came close to dispensing with markets $^{24}$ - even though they limited the operation of markets in many ways.

Contemporary participatory socialists seek to revive this marketless Marxist ideal, but in a manner very different from that of the Bolshevik tradition. First of all, they reject the authoritarian rule associated with the CP-directed socialist economies and insist instead on a democratic political framework. Second, they reject the hierarchical central planning apparatus that has hitherto been utilized as the main alternative to market exchange and insist instead on a process of decentralized planning in which people participate as equals.

Just as in the case of market socialism, ideas and conceptions of a marketless participatory socialism have been developed in various ways by various authors - starting with utopian socialists even before Marx and continuing through anarcho-syndicalists down to present-day advocates of democratic and participatory planning. Most recently, important contributions to the literature on participatory socialism - providing unusual and laudable detail on the actual institutions and functioning of decentralized democratic planning systems - have been published by Pat Devine and by Michael Albert and Robin Hahnel. ${ }^{25}$ These and other conceptions of participatory socialism differ in many respects, but they are all based on the replacement 
of market forces (which allocate resources by generating material incentives for individual economic agents acting in their own best interest) ${ }^{26}$ by a system of decentralized and coordinated planning (designed to allocate resources via negotiation among and between appropriately constituted groups of workers, consumers, community residents and citizens in general).

The basic decision-making units of the participatory system are typically workplace workers' councils and neighborhood consumers' councils, in which production and consumption decisions are made collectively by workplace and neighborhood communities, respectively. But these basic decision-making units are embedded in a larger network of related politically constituted bodies, designed to bring to bear relevant considerations and concerns that transcend the scope of individual workplaces and neighborhoods. A critical role in the network of nonmarket decision-making institutions is played by various planning boards, which are responsible for collecting and dispensing information and for coordinating the decisions of separate councils and entities in such a way that decentralized production and consumption plans emanating from all the workplaces and neighborhoods ultimately converge to a feasible overall pattern of production and consumption. The relevant information to be considered in decision-making includes both quantitative data about production and consumption processes and qualitative evidence about the ramifications of each production and consumption activity.

Advocates of this kind of participatory economic system assert that it can attain far more successfully than market socialism the socialist goals of egalitarianism, democracy and solidarity - because of the absence of markets - while performing at least as efficiently as a market system - in spite of the absence of markets. Advocates of market socialism, on the other hand, find this effort to do without market forces highly quixotic and thoroughly problematical; they question the feasibility of a participatory socialist system, and sometimes also its desirability. Some of the main concerns raised by critics of participatory socialism are reflected in the following questions:

1. Wouldn't the allocation of resources in a complex economy by means of participatory decision-making institutions place impossible demands on information processing and inordinate demands on people's time?

Since Adam Smith's original exposition of the mechanism of the "invisible hand," advocates of the market have celebrated its ability to process the enormous amount of information necessary for coordinated economic decision-making in a complex economy and to convey it in a simple way to individual economic actors, so that they have both the information and the incentive to act in an economically efficient manner. Most economists believe that the only other way that resources can be allocated in a complex economy is via a centralized, hierarchical system of administrative 
commands $^{27}$ - the system that has been so deeply discredited by the experience of the CP-directed socialist economies. Participatory socialists take up directly the challenge to develop a third resource allocational mechanism that avoids both the use of markets and the hierarchy of an administrative command system.

To replace the market without using administrative commands, they propose an enormous number and a vast network of decision-making bodies on which individuals will sit, process information, deliberate and arrive at decisions. Precisely because they don't trust the information summarized in and conveyed by market prices, they require these decision-making bodies to consider in detail both the qualitative and the quantitative implications of alternative ways of allocating resources. This places some staggering requirements on the system as a whole:

(a) to involve virtually everyone in the society in group decision-making processes;

(b) to compile an enormous amount of information about the economy and to make that information available in a timely and accessible way to individuals engaged in economic decision-making at one level or another;

(c) to develop a system of accounting - as a supplement if not an alternative to conventional market prices - that enables the social value of different production and consumption activities to be measured and compared, so that individual decision-makers can understand the aggregate social consequences of any given set of decisions;

(d) to find a way for the group of people involved in any given decision-making body to arrive in a reasonably harmonious and timely fashion at agreement on decisions; and

(e) to develop a system to assure that the myriad plans developed at the ground level of the decision-making network, when aggregated, converge to a consistent pattern of resource allocation for the economy as a whole.

The mere listing of these requirements is enough to generate skepticism about whether and how they can possibly be met. Even if, in principle, institutions and processes can be developed to accomplish the necessary tasks (and Albert \& Hahnel and Devine have advanced some ingenious ideas to do so), one is bound to wonder whether the whole system would actually function in practice. Assuming that computer technology could be relied upon to process and disseminate the enormous amount of information needed to make the system work, how would people be persuaded to provide the needed information in an unbiased and disinterested manner? And even if all the needed information could be accurately compiled, wouldn't participatory planning require each individual to dedicate so much time, interest and 
energy to assessing the information and participating in decision-making meetings that most people would get sick and tired of doing it?

2. Isn't the process of democratic decision-making sufficiently complex and problematic that it should be applied only to a limited range of critical decision-making areas?

Advocates of decentralized participatory planning to replace market forces generally place great weight on democracy - both as a desirable goal in itself and as the best means to arrive at decisions that truly reflect people's interests. In so doing, however, they tend to ignore the myriad problems involved in establishing fair and efficient democratic decision-making processes. First of all, choice among alternative voting conventions is complex and critical: when should decisions be made by simple majority, by a supermajority, or by consensus? What will distinguish constitutionally protected rights from those subject to democratic voting? If in principle people's votes on any particular issue should vary according to the extent to which they are affected by a decision, how should the weighing actually be determined in practice?

Explicitly political forms of economic decision-making are favored by advocates of participatory planning over impersonal and individual market processes, on the grounds that people should take explicitly into account the larger social context and the interdependence of their decisions. But won't the politicization of all kinds of decisions lead to excessive conflict, strife and anger and/or to the formation of political blocs and parties which tend to compress the great variety of individual views and preferences into lowest-common-denominator platforms and programs? Direct participatory democracy is generally favored over indirect representative democracy, on the grounds that people should be required to listen to and confront one another as directly as possible in arriving at decisions. But isn't the practice of participatory democracy sufficiently difficult, time-consuming and emotionally draining that it would in practice have to be limited to a relatively small range of decisions?

A system of decentralized and negotiated planning is expected by advocates of participatory socialism to assure egalitarianism in economic decision-making, yet in practice such a system might well enable some people to exercise much greater influence over decisions than others. Disproportionate influence would not arise from disproportionate wealth or income, but from disproportionate interest in and aptitude for the relevant decision-making processes. People are likely to vary greatly in terms of their ability to access and process information, to negotiate with others and to influence group decision-making; so political and economic inequalities can easily emerge in marketless as well as in market societies.

These kinds of concerns about the operation of democratic decision-making processes should not of course be read as a condemnation of democracy, 
much less as a plea for a purely free-market economic system or an authoritarian political system. Rather, such concerns suggest that democratic political institutions ought to focus on a critical and manageable range of decision-making arenas, rather than be used for all kinds of economic as well as political decisions. Direct voice in economic decision-making through negotiating and/or voting procedures is surely not the only, nor necessarily always the best, way for people to have their interests represented in the societal resource allocation process. People's individual and collective interests can often best be served by a combination of the opportunities for choice and exit provided by markets and the economic policy measures undertaken by democratically elected governments.

3. Wouldn't it be very wasteful to try to allocate labor without an incentive system that rewards individuals according to the market-determined value of their work contributions?

Albert \& Hahnel (1991a and 1991b) have argued that their participatory planning model actually has an important efficiency (as well as equity) advantage over market systems in its ability to reward people for work according to effort rather than according to result. They propose that the consumption opportunities available to individuals be linked to an individual's input into the production process - in the form of personal effort made or personal sacrifice endured. They criticize the market principle of linking individuals' rewards for work to the market-determined value of their output because the latter depends on variables over which individuals have little or no personal control - e.g., natural talent, job location, the vagaries of market demand.

Albert's and Hahnel's proposal would surely lead to greater equity in the reward for labor than the market-based alternative, ${ }^{28}$ but their claim of greater efficiency is misguided. They argue that it is most efficient for people to be rewarded according to their personal input because individuals would then be best motivated to supply the one factor which they actually control. Albert and Hahnel suggest that the alternative of a market-determined-output reward system is wasteful and misdirected because it rewards performance due in considerable part to factors beyond the individual's control. But the case for a personal-input reward system is flawed on two counts.

First of all, it is very difficult to observe and measure an individual's sacrifice or work effort and to determine how much of a work result was due to such personal input rather than to other aspects of the work. Measurable indexes of personal input would surely have to be quantitative in nature (e.g., time at work), for how could the quality of a person's effort be adequately measured? Any input-oriented incentive scheme would thus tend to encourage the substitution of quantity for quality of effort. Moreover, people would have an interest in understating their natural talents and 
abilities and in encouraging the perception that good performance had much more to do with their personal input than other factors, while bad performance was mainly the result of bad luck..$^{29}$

Second, even in the absence of any measurement problems, an incentive structure geared to reward individuals according to their personal input would be quite inefficient. Although it would presumably elicit greater work effort and sacrifice on the part of individuals, it would do nothing to assure that such effort and sacrifice were expended in a desirable way. The social good is best served by encouraging activities the results of which are highly valued relative to the cost of undertaking those activities. In order to motivate people to expend their efforts in a desirable way, it is therefore necessary to reward activities according to the value of work output rather than according to the quantity of work input. If market valuations of output do not adequately reflect the general social interest, then it follows that those output valuations ought to be modified accordingly - not that work should be rewarded according to an input measure instead. If one insists on ethical grounds that work be rewarded according to personal input, then one must be prepared to allocate resources by means that do not depend on the motivation of work via individual material reward.

4. Wouldn't a participatory economic system be viable only if there were a prior transformation of people's basic consciousness from one that is individually oriented to one that is socially oriented?

Advocates of market socialism assume that people will tend to behave as homo economicus and seek to attain the greatest possible individual rewards; they seek to achieve socialist goals by structuring the market environment in which self-interested individuals make their decisions, in such a way that people will choose to undertake economic actions in a socially desirable way. Advocates of participatory socialism are highly critical of such a market-oriented motivational scheme and seek to diminish the role of individual material incentives. But what alternative incentives are available? There are a number of possibilities. On the positive motivational side, people could derive satisfaction (a) from the intrinsic interest of the more enjoyable parts of their work, (b) from the social esteem that might accrue to them for a job well done and/or a social duty performed; (c) from the knowledge that they had met their responsibilities to others in the society, and/or (d) from a vicarious sharing in the enjoyment derived by others from consumption and production activities to which they contributed. On the negative motivational side, people could be discouraged from antisocial behavior by (e) the watchfulness and peer pressure of fellow consumers and workers, and/or (f) the practical inability of getting away with such behavior (whether it is excessively high consumption or excessively low production) in a society committed to egalitarianism. 
In order for such mechanisms to add up to a workable system of motivation which could substitute for individual material incentives, there would surely have to be a wholesale conversion of human behavior patterns from homo economicus to what might best be characterized as homo socialis - i.e., a person whose very consciousness was socially rather than individually oriented. It is a fundamental premise of Marxism that people are strongly influenced by their socioeconomic environment - that people's values and behavior can and will become different as historical and socioeconomic conditions change. Accepting this premise, one can envisage that in a participatory economic environment people might develop the solidaristic attitudes and cooperative capabilities which would make a participatory socialist system work. What remains to be examined, however, is the process whereby both the needed institutions and the needed values and behavior patterns would emerge. I will return to this question in the final section of the paper.

5. Wouldn't a participatory economic system tend to be too intrusive in restricting individuality, privacy and freedom of choice? ? $^{30}$

Critics of participatory socialism question whether it can adequately protect the legitimate interests of those who hold and wish to act on minority views. True democracy requires not only that people have more or less equal influence over decisions that affect them to the same degree, but that minorities be protected from majority decisions - however equally and fairly they are arrived at - which disadvantage them in important ways. Under participatory socialism there are many important decision-making bodies that are expected to operate by majority vote. Citizens are expected to exercise a great deal of voice in participating in these decision-making bodies. If a decision doesn't go the way of a particular individual or group, however, the opportunities for exit are limited: changing workplaces or neighborhoods in order to enter new decision-making groups remains possible, but one cannot be confident that this would be easy to do in practice. ${ }^{31}$

Although not a goal that is usually voiced explicitly by socialists, freedom of choice - in how to live, what to consume, what kind of work to do, how to express oneself, how to define one's social identity, etc. - is an important value. A participatory system is likely to require people to justify many of their choices along these lines to some kind of collective decision-making body, which in turn is bound to limit the extent to which people can really get their choices accepted - no matter how democratically decision-making bodies are constituted..$^{32}$ By enabling individuals to make most choices without reference to what others think about their decisions, a market system provides much greater freedom of this kind. Of course it does so only for people who have the wherewithal to afford alternative choices; 
thus for a market system to promote meaningful freedom of choice for all, the distribution of income must be reasonably equitable.

In order to avoid the hierarchy of power, income and prestige that tends to develop when people specialize in particular jobs, Albert and Hahnel (1991a and 1991b) have proposed that "balanced job complexes" be established in participatory socialist societies. Under this plan each individual would engage in a variety of work tasks with varying degrees of desirability, combined into a job complex that would be characterized by an average degree of pleasantness comparable to that of every other individuals' job complexes. But many people are likely to prefer doing more specialized work activities than would be permitted under such a balanced-job-complex requirement, which means that enforcement of the requirement might well involve implicit or explicit coercion. Moreover, many people might well prefer to have certain activities carried out by other specialists rather than by participants rotating through from the rest of their balanced job complexes; not just brain surgery and airplane piloting come to mind here, but also such everyday activities as teaching, writing and the performance of music, art and sports. Apart from their inhibition of personal freedom, balanced job complexes designed to avoid specialization seem likely to deprive society of the benefits of activities performed well only by people who have devoted a disproportionate amount of time and effort to them. ${ }^{33}$

These kinds of questions about the desirability of participatory socialism stem from the attribution of fundamental value to a significant degree of individuality, privacy and freedom of choice - in addition to and alongside the more traditional socialist goals of equity, democracy and solidarity. The more weight one places on the former kind of objectives, the more skeptical one will be about the desirability of participatory socialism.

\section{CONCLUSION}

Having raised many of the arguments both for and against the variants of socialism with the strongest claims to a future, I turn now to an attempt to decide on the one that offers the most promise to achieve the basic goals of socialism. The most important choice to be made is between market socialism and participatory socialism. Before turning to that choice, however, it will be useful to consider what kind of market socialism provides the best alternative to participatory socialism.

\section{A. Public Enterprise vs. Worker Enterprise Market Socialism}

Market socialism calls for the replacement of private by social control and income rights within a (government-guided)-market environment. An important question for advocates of market socialism is whether to base the social rights on communities of citizens or workers. Should control rights the rights to manage the enterprise - be vested in governmental agencies 
(democratically accountable to electorates of citizens) or in workers' councils (democratically accountable to electorates of enterprise workers)? Should income rights - the rights to the surplus generated by the enterprise accrue to the general public (via government agencies) or to enterprise workers?

Advocates of public management stress its advantages vis-à-vis worker self-management with respect to "capital efficiency" - access to capital funds, encouragement of risk-taking, technological progress, etc. Advocates of public surplus appropriation stress its advantages with respect to equity at the societal level: channeling the residual income of enterprises into an aggregate "social dividend" recognizes the interdependence of all production activities, protects workers and citizens against the potential risk and inequity of having their capital income tied to the performance of a particular enterprise (which may do well or do badly for reasons of luck rather than merit) and can distribute society's surplus much more equitably than when individual enterprises retain much of their own surplus.

Advocates of worker self-management stress its advantages vis-à-vis public management in several different respects: (1) "labor efficiency" motivation of work effort and quality, disciplining of management, organizational improvement, etc; (2) democracy: worker self-management at the enterprise level is in and of itself democratic, and may well reinforce democracy at the political level; and (3) solidarity: through greater participation in workplace and enterprise decision-making, workers may gain a stronger sense of solidarity with their fellow workers. Advocates of worker surplus appropriation stress its advantages with respect to labor efficiency and solidarity, as workers' incomes are linked collectively to the performance of their enterprises.

Clearly there are significant trade-offs here. Different kinds of social control rights are advantageous with respect to different kinds of efficiency considerations, and different kinds of social income rights are advantageous with respect to different socialist objectives of equity, democracy and solidarity. A reasonable solution to the dilemma of choice - consistent with the overall spirit of compromise inherent in market socialism - would be to encourage a mixture of public and worker control and income rights, emphasizing each in the particular circumstances in which it would do the most good. Such a compromise could take the form of promoting public management in those industries and enterprises characterized by relatively large economies of scale and/or relatively extensive externalities, and promoting worker self-management in industries and enterprises with smaller economies of scale and/or less significant externalities. Since income, unlike control, can easily be shared, it might well be best to promote patterns of enterprise income rights in which there is both a social dividend claim and an enterprise worker claim. 


\section{B. Market Socialism vs. Participatory Socialism}

To make this choice, socialists must confront two major, separable issues. The first issue is whether and how people could be expected to change from homo economicus, as we know him/her in contemporary capitalist societies, to homo socialis, as he/she is depicted in the operation of participatory socialist societies. The second issue is how much value we should attach to the opportunity for individuals to exercise such libertarian rights as freedom of choice, privacy and the development of one's own specialized talents and abilities - as compared to the more traditional socialist goals of equity, democracy and solidarity.

In the effort to build a socialist society, market socialists take the terrain of homo economicus to be the relevant one - at least for the present and the foreseeable future. If people act essentially as homo economicus, it follows that a significant amount of inequality, hierarchy, competition, etc., is a necessary ingredient of an efficient economic system; and this is one important reason for the market socialist acceptance of markets. Participatory socialists, on the other hand, believe that, for the construction of socialism within the foreseeable future, homo economicus need not be an unalterable fact. They argue (with Marx) that homo economics is the result of a particular pattern of historical development (and a related pattern of unequal power), which can be changed if people decide do so and act collectively on that desire. The struggle for homo socialis can itself help to bring about the desired change in human values and behavior, which would then permit the socialist goals of equity, democracy and solidarity to be achieved with reasonable efficiency under a system dependent on participation and cooperation rather than autonomy and competition.

Many market socialists - for example, Alec Nove (1991; Part 1) dismiss the idea of homo socialis as utopian, and on that basis reject participatory socialism as utterly irrelevant to the fashioning of a "feasible" socialism for the foreseeable future. In the previous section I raised many of the arguments with which skeptics question the feasibility of a participatory economy, and these arguments have made a skeptic of me. I believe, however, that even if we skeptics are wrong about the potential viability of homo socialis, there remains a solid reason for turning away from the communitarian vision of socialism.

Consider what it would take to move from here to there. The same Marxist reasoning which suggests that homo socialis is perfectly possible, within an appropriately symbiotic institutional context, suggests that people who have been living in a capitalist institutional environment will be deeply imprinted with the characteristics of homo economicus. ${ }^{34}$ To transform homo economicus into homo socialis would thus involve a massive change in people's mind-sets. Such a transformation might conceivably be imposed on a society by an authoritarian elite, but it is virtually impossible to imagine 
it being generated by a democratic process that respected the current attitudes and preferences of the general public.

This reasoning does not rule out the possibility of any kind of democratic social change from contemporary conditions. It does suggest, however, that such change must be gradual enough so that it is realistic to expect that people - as they are, in their current socioeconomic environment - can be persuaded of the desirability of the change. This seems to me a compelling reason for pursuing socialism in terms of the more modest ambitions of market socialists. Even if one's ultimate hope is to progress to a participatory form of socialist society, a gradual move to some form of market socialism - which would begin to change people's actual socioeconomic environment in a more socialist direction - would appear to be a necessary first step in achieving a democratic transition.

Whether a subsequent transition from market socialism to participatory socialism would in fact be desirable remains an open question. In my discussion of participatory socialism in the previous section, I suggested that certain libertarian objectives associated with personal freedom of choice can best be satisfied only if individuals have the kind of opportunities for choice (and for exit) that a market system alone can provide. While the replacement of markets with a participatory economic system - if feasible - would arguably contribute to a more egalitarian, democratic and solidaristic society, the point is that it would appear to do so at a cost in terms of libertarian objectives.

It is undeniable that such libertarian objectives smack of "bourgeois rights," while the objectives of equality, democracy and solidarity have traditionally been the most strongly associated with socialism. I submit, however, that both kinds of objectives are important ingredients of a good society, and that the task for socialists is to assure the attainment of both in significant measure. I therefore believe that market socialists are right to opt for a significant role for markets, recognizing that this involves a sacrifice of some degree of equality, democracy and solidarity, but expecting that it will deliver more respect for individuality and privacy and more freedom of choice.

\section{Democratic Self-Managed Market Socialism}

I have thus concluded with an endorsement of market socialism. To emphasize that democracy should be the essential cornerstone of the socialist project - in the process of transition as well as in the organization of institutions - I include the word "democratic" in my characterization of market socialism. And to emphasize that democracy must be extended from the political to the social to the economic sphere of life, I include also the word "self-managed." 
A democratic self-managed market socialism combines:

(1) A liberal democratic political framework, under which government (at all levels) is accountable to citizens via regular democratic elections in a context of civil rights and civil liberties, and participatory democratic mechanisms are promoted at local levels where direct participation is feasible.

(2) Social rights to the control and the income of enterprises (above a modest size), with these rights to be divided between communities of citizens and communities of workers according to pragmatic criteria.

(3) Markets as the predominant mechanism for resource allocation, providing informational and incentive benefits as well as freedom of choice, with the opportunities for exit afforded by markets complementing the opportunities for voice afforded by participatory democracy in local politics and enterprise self-management.

(4) A significant economic and social policy role for the state, whereby the market is rendered the servant rather than the master of society: the national government formulates and implements overall macroeconomic policy, influencing but not controlling the rate and pattern of investment, and also undertakes microeconomic intervention as needed to achieve important goals - not only via taxes and subsidies but also by directly providing certain goods and services (e.g., capital or consumption goods with strong public good characteristics), by assuring general social security (to maintain economic welfare for all), and by pursuing active labor market policies (to keep unemployment down).

However attractive and convincing this vision of socialism may be to its advocates, we must recognize that its general appeal is still very limited. On the Right, it confronts powerful political forces and a powerful ideology favoring capitalism over socialism. On the Left, it faces obstacles even among people upset with the present system, convinced of the need for fundamental change and ready to embrace some form of socialism.

The problem is that the call for market socialism is simply not the kind of clarion call that is emotionally satisfying or politically inspirational; the case for market socialism is all too reasoned, too balanced, too moderate. This is its virtue, but also its Achilles' heel. Who will rally behind its banner? If it is ever to get anywhere, it will need the backing of a strong political movement; and a political movement needs powerful rallying cries and effective popular mobilization to get off the ground. Democratic self-managed market socialism needs to resonate more fully and more clearly with public hopes and aspirations, or it is likely to remain a socialism for the future but not of the future. 


\section{NOTES}

1. I will consistently use the term "Communist-Party-directed" (or the abbreviated "CP-directed") to describe the kind of socialism that has actually existed in the Soviet Union, Eastern Europe, China, Cuba, Vietnam and North Korea. There are of course many other adjectives that have been used to characterize this type of socialism "actually existing," "buresucratic state," "centrally planned," etc. - and some have even called it a form of (state) capitalism. I prefer "CP-directed" because it underlines in a compact way the authoritarian, hierarchical, bureaucratic nature of both the political and the economic system.

2. A complete balance sheet on CP-directed socialism in Eastern Europe and the Soviet Union would have to include also such positive achievements as the public provision of free education and health care (among other social services), the availability of low-cost transportation and housing and greater public access to culture - however modest and restricted some of these benefits may have been. For an insightful attempt to draw such a balance sheet, see Peter Marcuse's (1991) account of his experience in East Germany when the old system was crumbling in 1989-90. 3. This is the implication of a quotation from Serge Mallet that I and my co-authors endorsed in the introductions to all three editions of Edwards, Reich and Weisskopf $(1972,1978,1986)$. Mallet $(1970: 45)$ asserts that the societies of the Soviet Union and Eastern Europe are to true socialism "what the monsters of the paleolithic era are to present animal species: clumsy, abortive prototypes."

4. I do not include Trotskyist Marxists among those who have consistently rejected CP-directed socialist systems because - although they have been among the most acerbic critics of Stalinism and of the Soviet Union for at least half a century - they do not reject all forms of communist party control over socialism.

5. Liberal-democratic socialists are for the most part not closely associated with Marxism; however, some do consider themselves Marxist and see Communist Parties as having betrayed the principles of Marxism. The most prominent liberal-democratic socialists in the United States are associated with Dissent magazine, notably the late Michael Harrington; see, for example, Harrington (1989).

6. Communitarian socialists include Marxists who identify with Marx's long-run vision of a truly communist society as well as "new Leftists" who reject many elements of the Marxist tradition. One of the best known exponents of this school of thought in the United States is Noam Chomsky; for a detailed discussion of what a communitarian socialist society would look like, see Albert and Hahnel (1991).

7. See Lange (1936-37) and Lange and Taylor (1938). Abba Lerner also made seminal contributions to the early literature on market socialism; see Lerner (1934) and (1936).

8. For a brief survey of the history of the idea of market socialism, see Brus (1987); for a recent contribution to the literature on conceptualizing market socialism, see Nove (1991).

9. In this context the enterprise surplus should be defined to include also any capital gains or losses.

10. Examples of recent models of market socialism characterized by public management include those of John Roemer (1991) and Leland Stauber (1977). 
11. Examples of recent models of market socialism featuring worker self-management include those of David Schweickart (1980) and David Ellerman (1990) - though in Schweickart's model the national government retains control over net capital formation, and Ellerman does not explicitly use the term "market socialism".

12. For example, in Roemer's model of market socialism, (most of the) enterprise surpluses flow back to the national government to be distributed (in large part) to the general public in an equitable manner as a "social dividend"; in Stauber's model, local government agencies receive enterprise capital income qua shareholders and either use it for local public purposes or redistribute it to local citizens.

13. For example, in both Schweickart's and Ellerman's models of worker self-management, the enterprise surplus accrues strictly to its workers - though there are taxes and/or other charges which must first be paid to government.

14. Roemer's and Stauber's models of market socialism represent different kinds of public enterprise models, while Ellerman's is a worker enterprise model; Schweickart's is predominantly a worker enterprise model, but includes some characteristics of a public enterprise model - e.g., government control over net capital formation.

15. Market valuations are expected to reflect "true" social benefits and costs to a much greater extent under market socialism than under capitalism not only because of the greater degree of internalization of externalities, but also because of the more equal distribution of income that results from the socialization of enterprise income rights; thus overall market demand will not disproportionately reflect the demands of a minority of wealthy individuals.

16. The elimination of rewards to property ownership under market socialism is not complete because most market socialist proposals allow for some private ownership of small businesses and for some payment of interest-type returns on individual savings.

17. Progressive taxation is of course also possible in market capitalist systems, but it is surely more likely to be successfully instituted in a market socialist system because of its greater overall economic and hence political equity.

18. This term "coordinator" has been introduced by Albert and Hahnel (1981) to characterize the managers and beneficiaries of the CP-directed socialist economies, but it would seem equally appropriate as a term to characterize any small group of people who are able to parlay critical decision-making roles in a social system into disproportionate political and economic power.

19. See Bowles (1991) for a very suggestive analysis of the impact of markets, as cultural institutions, on the process of human development.

20. This evolution in the thinking of advocates of market socialism toward an increasing role for markets can be seen very clearly in the differences between Brus (1972) and Brus and Laski (1989).

21. Some critics of market socialism have argued that a market socialist system is fundamentally unstable, bound to veer back to a form of capitalism under the pressures on enterprises imposed by competition in a market environment. Certainly market competition restricts the scope of viable options for any kind of producing enterprise; but the argument that it obliterates distinctions among enterprise types is based on a very unrealistic economic model of capitalism - one in which "black-box" firms face no problems of contract enforcement, worker motivation, etc.; only under such restrictive assumptions is there no room at all for discretionary 
decision-making by firm management and is the market all-determining. For a stimulating debate on these issues, see the exchange between Arnold (1987) and Schweickạt (1987).

22. As Miller (1989: 30) has put it: "for markets to operate effectively, individuals and enterprises must receive primary profits, but the proportion of those profits that they need to keep as private income depends on how far they require material (as opposed to moral) incentives."

23. The experience of Sweden since the mid-1970s is often cited to show the vulnerability of social democracy to pressures to move toward a more traditional form of capitalism. For informative analyses of the trials of the Swedish model of social democracy in recent years, see Lundberg (1985) and Pontusson (1987).

24. The period of "War Communism" in the Soviet Union during the civil war years immediately after the Bolshevik Revolution constitutes an exception to this assertion, but of course one associated with exceptional circumstances.

25. See Devine (1988) and Albert and Hahnel (1991a) and (1991b); of the Albert and Hahnel works, the former is a highly accessible popular presentation of their model, while the latter provides a more rigorous and technical presentation of their ideas.

26. Devine (1988) takes pains to distinguish between "market exchange" and "market forces"; the latter is distinguished from the former as the process whereby "change [in the economy] occurs ... as a result of atomized decisions, independently taken, motivated solely by the individual decision-makers' perceptions of their individual self-interest" (p. 23).

27. I refrain deliberately from using the term "central planning" to describe this system, since the literature on such systems demonstrates clearly that their planning mechanisms have been unable to bring about the coordinated fulfillment of any kind of consistent central plan; see, for example, Wilhelm (1985).

28 . On the other hand, if equity were really the primary concern, why not reward people according to their need instead of their work input - in other words, why not replace Albert's and Hahnel's version of the socialist distributional principle with Marx's communist principle?

29. It is of course often difficult to measure the result or output of an individual's work, but the difficulties in measuring work output are qualitatively less significant then the difficulties associated with measuring an individual's work input. The former difficulties have mainly to do with distinguishing the contributions of different workers to a joint output, while the latter have to do with disentangling an individual's personal effort from the person's natural abilities.

30. Many of the issues raised here about the desirability of participatory socialism have already been discussed in a persuasive critique of Albert and Hahnel (1991a) by Folbre (1991: 67-70).

31. Of course, changing workplaces or neighborhoods is not that easy to do in practice for many people in market economies either; but the point is that market economies offer individuals or minorities other kinds of opportunities for exit when they make choices that differ from those of the relevant majority.

32. Even the option of switching workplaces and neighborhoods, or forming new ones, does not completely overcome this problem; aside from any difficulties in effecting such switches, there will be societal rules in a participatory economy which every workplace and neighborhood must adhere to, and no doubt many issues of interpretation of those rules which will call for socially determined decisions. Of course, even the most individualistic society must adhere to some rules if it is to 
survive at all; but the point is that societal rules loom more important in a communitarian society in which people's responsibility to one another is elevated to a guiding principle.

33. As Moore (1980) has argued forcefully in a critique of Marx's vision of full communism, the material basis of cultural complexity is precisely the division of labor.

34. The same surely holds true for people who have been living in a CP-directed socialist institutional environment, where the motivational system remained rooted in individual material incentives.

\section{REFERENCES}

Albert, Michael and Robin Hahnel. 1981. Socialism Today and Tomorrow. Boston: South End Press.

1991a. Looking Forward: Participatory Economics for the Twenty First Century.

Boston: South End Press. .1991b. The Political Economy of Participatory Economics. Princeton, NJ: Princeton University Press.

Arnold, N. Scott. Marx and Disequilibrium in Market Socialist Relations of Production. Economics and Philosophy 3(1).

Bowles, Samuel. 1991. What Markets Can - and Cannot - Do. Challenge (July-August).

Brus, Wlodzimierz. 1972. The Market in a Socialist Economy. London: Routledge \& Kegan Paul.

1987. Market Socialism. In, The New Palgrave: A Dictionary of Economics, John Eatwell, Murray Milgate and Peter Newman (eds.), London: MacMillan.

Brus, Wlodzimierz and Kazimierz Laski. 1989. From Marx to the Market. London: Oxford University Press.

Devine, Pat. 1988. Democracy and Economic Planning. Boulder, CO: Westview Press.

Edwards, Richard C., Michael Reich and Thomas E. Weisskopf. 1972, 1978, 1986. The Capitalist System. Garden City, NJ: Prentice-Hall.

Ellerman, David. 1990. The Democratic Worker-owned Firm. Winchester, MA: Unwin Hyman.

Folbre, Nancy. 1991. Contribution to Looking Forward: A Roundtable on Participatory Economics, $Z$ Magazine (July-August).

Harrington, Michael. 1989. Socialism, Past and Future. Boston: Little Brown.

Heilbroner, Robert. 1989. Interview under the heading No Alternatives to Capitalism. New Perspectives Quarterly (Fall).

Lange, Oskar. 1936-37. On the Economic Theory of Socialism. Part 1 and 2, Review of Economic Studies 4.

Lange, Oskar and Fred Taylor. 1938. On the Economic Theory of Socialism. Minneapolis: University of Minnesota Press.

Lerner, Abba. 1934. Economic Theory and Socialist Economy. Review of Economic Studies 2. . 1936. A Note on Socialist Economics. Review of Economic Studies (4).

Lundberg, Erik. 1985. The Rise and Fall of the Swedish Model. Journal of Economic Literature 23(1).

Mallet, Serge. 1970. Bureaucracy and Technology in the Socialist Countries. Socialist Revolution 1(2).

Marcuse, Peter. 1991. Missing Marx: A Personal and Political Journal of a Year in East Germany, 1989-90. New York: Monthly Review Press.

Miller, David. Why Markets? In, Market Socialism, Julian Le Grand and Saul Estrin, (eds.). London: Oxford University Press.

Moore, Stanley. 1980. Marx on the Choice between Socialism and Communism. Cambridge, MA: Harvard University Press. 
Nove, Alec. 1991. The Economics Of Feasible Socialism Revisited. London: Harper-Collins Academic.

Pontusson, Jonas. 1987. Radicalization and Retreat in Swedish Social Democracy. New Left Review \#165.

Roemer, John. 1991. The Possibility of Market Socialism. Working Paper No. 357, Department of Economics, University of California, Davis.

Schweickart, David. 1980. Capitalism or Worker Control? New York: Praeger. . Market Socialist Capitalist Roaders. Economics and Philosophy 3(3).

Stauber, Leland. 1977. A Proposal for a Democratic Market Economy. Joumal of Comparative Economics 1(3).

Weisskopf, Thomas E. 1991. The Drive Toward Capitalism in East Central Europe: Is There No Other Way? Working Paper, Department of Economics, University of Michigan. 1992. Challenges to Market Socialism: A Response to Critics. Dissent (Spring).

Wilhelm, John. 1985. The Soviet Union has an Administered, not a Planned, Economy. Soviet Studies 37. 